Author 1 Name: Timo Dietrich

Department: Social Marketing @ Griffith

University/Institution: Griffith University

Town/City: Brisbane

State (US only):

Country: Australia

Author 2 Name: Sharyn Rundle-Thiele

Department: Social Marketing @ Griffith

University/Institution: Griffith University

Town/City: Brisbane

State (US only):

Country: Australia

Author 3 Name: Lisa Schuster

Department: Social Marketing @ Griffith

University/Institution: Griffith University

Town/City: Brisbane

State (US only):

Country: Australia

Author 4 Name: Jason Connor

Department: Centre for Youth Substance Research and Discipline of Psychiatry

University/Institution: University of Queensland

Town/City: Brisbane

State (US only):

Country: Australia

Corresponding author: Timo Dietrich

Corresponding Author’s Email: t.dietrich@griffith.edu.au 


\title{
A systematic literature review of alcohol education programmes in middle and high school settings (2000-2014)
}

\begin{abstract}
Purpose - Social marketing benchmark criteria were used to understand the extent to which single-substance alcohol education programmes targeting adolescents in middle and high school settings sought to change behaviour, utilised theory, included audience research and applied the market segmentation process.
\end{abstract}

Design/methodology/approach - A systematic literature review retrieved a total of 1495 identified articles; 565 duplicates were removed. The remaining 930 articles were then screened. Articles detailing formative research or programmes targeting multiple substances, parents, families and/or communities, as well as elementary schools and universities were excluded. A total of 31 articles, encompassing 16 qualifying programmes, were selected for detailed evaluation.

Findings - The majority of alcohol education programmes were developed on the basis of theory and achieved short and medium term behavioural effects. Importantly, most programmes were universal and did not apply the full market segmentation process. Limited audience research in the form of student involvement in programme design was identified.

Research limitations/implications - This systematic literature review focussed on singlesubstance alcohol education programmes targeted at middle and high school student populations, retrieving studies back to the Year 2000.

Originality/value - The results of this systematic literature review indicate that application of the social marketing benchmark criteria of market segmentation and audience research may represent an avenue for further extending alcohol education programme effectiveness in middle and high school settings.

Keywords - Systematic review, Alcohol, Schools, Social marketing, Segmentation, Audience research, Theory

Paper type - Literature review 


\section{Introduction}

Reducing alcohol consumption among adolescents is one of the foremost challenges facing developed nations (Roche et al., 2010; National Preventative Health Taskforce [NPHTF], 2008). In many countries, excessive alcohol consumption is culturally accepted and encouraged. In Australia, for example, excessive drinking is regarded as a badge of honour and often celebrated (Shanahan et al., 2002). Evidence suggests that high-level alcohol consumption damages adolescents' developing brain and affects behavioural and cognitive functioning (Squeglia et al., 2009). Further, the age of alcohol consumption onset is a strong predictor of subsequent problematic alcohol use (Ellickson et al., 2003; Lloyd et al., 2000), with many national drinking guidelines now recommending delaying initiation of drinking as long as possible (National Health and Medical Research Council [NHMRC], 2009). The significant social and economic impacts of alcohol drinking in adolescence highlight the importance of education programmes, which are more cost effective than treatment (Goetzel, 2009). Schools are the most cost effective face-to-face environments to reach adolescents through education programmes (Babor et al., 2010). Consequently, school-based alcohol education programmes play an important role in attempting to shift drinking attitudes and behaviours (e.g. Botvin and Griffin, 2007; McBride et al., 2004).

The Cochrane Collaboration has conducted systematic reviews on randomised trials evaluating universal school-based alcohol education programmes (see Foxcroft and Tsertsvadze, 2012; Foxcroft et al., 2003). Although the recent review of more than 50 programmes was not able to distinguish key characteristics or mechanisms influencing programme effectiveness, the more promising programmes were those that focused on generic psychosocial or developmental factors (Foxcroft and Tsertsvadze, 2012). Norm setting and peer resistance skill training are exemplar components of psychosocial 
programmes that aim to foster young people’s skills in social settings (Foxcroft and Tsertsvadze, 2012). Other meta-reviews (e.g. Tobler and Stratton, 1997), systematic reviews (e.g. Dusenbury et al., 1997; McBride, 2003) and literature reviews (e.g. Roche et al., 2010; Stigler et al., 2011) have identified key principles underpinning effective drug education programmes in schools. It is recommended, for example, that programmes are interactive (discussions, role-play, group activities, online activities), theory based (guided by comprehensive theoretical frameworks), developmentally appropriate (programme is designed to age group), culturally sensitive (relevant language and context), normative in approach (correct information regarding alcohol and drug usage), foster personal and social resistance skills (build resilience skills and self-confidence), incorporate booster sessions (reinforce messages) and that teacher training is included (briefing manuals and/or workshops) (Botvin and Griffin, 2004, 2007; Cuijpers, 2002; Dusenbury et al., 1997; Foxcroft and Tsertsvadeze, 2012; Tobler and Stratton, 1997; Roche et al., 2010; Stigler et al., 2011). Despite these undoubtedly valuable insights, no one approach or combination of approaches has been found to achieve long-term behaviour change effects (Flay, 2000; Foxcroft and Tsertsvadze, 2012; Teesson et al., 2012; White and Pitts, 1998). One potential avenue for providing new insights into increasing the effectiveness of alcohol education programmes in school settings is social marketing.

Social marketing is the adaption of commercial marketing techniques to programmes designed to influence voluntary behaviour for social good (Lee and Kotler, 2011). Previous research shows that programmes that adopt social marketing benchmark criteria, including a focus on behaviour change, audience research, segmentation and using theory in programme development, are more effective (e.g. Carins and Rundle-Thiele, 2013; Gordon et al., 2006; Stead et al., 2007, Truong, 2014). Social marketing benchmark criteria have been used in 
programmes directed at reducing excessive alcohol consumption in a number of multi-faceted contexts. These contexts include universities (Glider et al., 2001; Gomberg et al., 2001; Vinci et al., 2010), drunk driving (Rothschild et al., 2006), pregnant women (Glik et al., 2008), community-based approaches (Kypri et al., 2005; Kypri and Dean, 2002; Rowland et al., 2013), programmes for paediatricians (Payne et al., 2011) and multi-substance approaches (Hastings et al., 2002; Slater et al., 2006). Andreasen (1994, 2002) described six criteria which have been generally accepted as the benchmarks for a social marketing approach, although it is acknowledged that not all criteria need to be applied (Andreasen, 2002). These criteria are: behaviour change, audience research, segmentation, exchange, marketing mix and competition. More recently, the National Social Marketing Centre (French and BlairStevens, 2006) expanded upon Andreasen’s (2002) six social marketing benchmark criteria by adding two additional criteria, theory and consumer insight.

The evaluation of the application of social marketing benchmark criteria to alcohol education programmes in middle and high school settings has received limited attention (Hastings et al., 2002; Rundle-Thiele et al., 2013). This research reviews the extent that school-based alcohol education programmes apply selected social marketing benchmark criteria, namely behaviour change, theory, audience research and segmentation. The behaviour change criterion contends that programmes should possess a behavioural aim that extends beyond attitude change, such as the reduction of binge drinking. Since the benchmark criteria of audience research and consumer insight are not mutually exclusive, making classification difficult (Gracia-Marco et al., 2011), one combined criteria (audience research) was included in this review. The criterion of audience research suggests that a deep understanding of the target audience needs to be generated by conducting rigorous formative research. This bottom-up philosophy of social marketing purports that solutions arise from listening to, and co-creating 
meaningful offerings with, the target audience (Andreasen, 1994; Lefebvre 2013).

Segmentation refers to grouping individuals into homogenous segments (or groups) based upon similar demographic, geographic, psychographic and behavioural characteristics (Kotler and Armstrong, 2001; Lee and Kotler, 2011). Segmentation permits the selection of target segments or groups for which tailored messages aligned with their needs and wants can be delivered to maximise change outcomes. Last, social marketing proposes programme design should involve the use of a theoretical framework within programme development, audience research, segmentation, intervention design, message formation or evaluation (Truong, 2014).

Employing only selected social marketing benchmark criteria deviates from previous reviews (e.g. Carins and Rundle-Thiele, 2013; Janssen et al., 2013; Stead et al., 2007). It is important to note, however, previous reviews also vary in their approach and assessment of the benchmark criteria. Stead and colleagues (2007), for example, evaluated programmes targeting alcohol, tobacco, illicit drugs and physical activity against all six of Andreasen's social marketing benchmark criteria. In contrast, Carins and Rundle-Thiele (2013) assessed only self-described social marketing programmes for healthy eating against the six benchmark criteria. Similarly, Janssen and colleagues (2013) included only self-described social marketing programmes targeting alcohol-related behaviours, but assessed the identified programmes against the NSMC’s eight benchmark criteria. Although these approaches are certainly valid, this review assumes the position articulated by Rothschild (1999) in his seminal paper describing the purpose and function of education, social marketing and law as tools for social change. According to Rothschild (1999), education’s strength lies in informing and/or persuading target audiences and therefore, “education, if alone, can suggest an exchange, but cannot deliver the benefit of exchange explicitly” since it does not employ the marketing mix. Social marketing's contribution is thus that it offers "a direct and timely 
exchange” through the "development of choices with comparative advantage (products/services), favourable cost-benefit relationships (pricing), and time and place utility enhancement (channels of distribution) (Rothschild, 1999, p. 25). From this perspective, the criteria of exchange, competition and the marketing mix are outside the scope of alcohol education programmes targeted at middle and high school students and subsequently not included in this systematic literature review.

\section{Method}

Several PRISMA reporting guidelines were followed during the systematic review process, including the use of cross raters, repeated database searches and researcher consensus processes during categorisation (Moher et al., 2009). The aims of this systematic literature review were to identify English language studies of single-substance alcohol education programmes in middle and high school settings published in journals since 2000; and to understand the extent that selected social marketing benchmark criteria (behaviour change orientation, theory application, audience research and segmentation) were used in existing alcohol education programmes. A search of the literature was conducted across 13 databases (Proquest Education Journals, Sociological Abstracts, ERIC, PsycINFO, PubMed, A+Education, CINAHL, Medline, Business Source Complete, Drug Database, Science Direct, Emerald Fulltext, Web of Science), with the last search conducted at the end of November 2013. For six of these databases, alerts were set-up so that newer articles could also be retrieved post the initial search date. However, none of the alerts resulted in the addition of studies prior to completion of this review. The search terms included: alcohol, intervention, randomised controlled trial, curriculum, evaluation, program, school, teenager, youth, adolescent and numbers 14, 15, and 16. For this study, the authors focussed only on 
school-based alcohol education programmes. The year 2000 was selected as a starting point for the review in order to limit the results to contemporary programme design.

The search process was undertaken as follows. First, two independent researchers conducted the database search at separate locations. A match rate of $99.7 \%$ was achieved. A total of 1,495 articles were identified and after the removal of 565 duplicates, the remaining 930 articles were then screened using their abstracts. As illustrated in Figure 1, 902 articles were omitted based upon the predefined exclusion criteria. Articles detailing formative research and programmes targeting multiple substances, parents, families and/or communities, as well as elementary schools and universities were excluded (see Figure 1 which lists exclusion criteria). A backward and forward search resulted in the inclusion of 20 additional articles. Forty-eight articles were selected for full text review and were evaluated once more against the aforementioned exclusion criteria. As a result, 17 articles were omitted. A total of 16 programmes, summarised in 31 articles, were next examined by two researchers to determine the extent to which the selected social marketing benchmark criteria were applied. Where differences were observed, a consensus process was used to ensure consistent interpretations.

The two researchers independently reviewed each article with a particular focus on the application of selected social marketing benchmark criteria; namely, behaviour change (and other outcome variables), audience research, segmentation and theory application (see Table 1). Behaviour and other change outcomes were summarised. Audience research was evaluated based upon reports of student and other stakeholder contributions to programme design, implementation and/or evaluation. The programme was regarded as underpinned by theory when at least one instance of specific theory application was reported (Truong, 2014). Segmentation required indication of a process similar to the three step model of 
segmentation, which involves segmentation (reported by some form of cluster analysis), followed by a decision to target one or more segments and positioning to meet the wants and needs of the target segment(s) (Elliott et al., 2012). An additional column (targeting) was included in Table 1 to describe the audience targeted by each programme. The targeting criterion was met when a programme targeted one or more specific groups, for example, high-risk students (e.g. Conrod et al., 2006, 2008). Programmes delivered to the entire cohort were categorised as universal programmes (e.g. McBride et al. 2000a; Rundle-Thiele et al., 2013; Vogl et al. 2009).

\section{INSERT FIGURE 1 HERE}

\section{Results and Discussion}

The findings of the systematic literature review are presented in Table 1. This table delineates the extent to which each of the 16 school-based alcohol education programmes included in the review: (1) reported behavioural and other change outcomes, (2) employed theory, (3) conducted audience research and (4) applied segmentation (including targeting). The sections following Table 1 provide a summary of the findings with regards to programmes' application of the four social marketing criteria, starting with the extent to which they reported behavioural effects and concluding with the application of segmentation. Each criterion and their characteristics will be discussed. These sections highlight selected programmes to serve as illustrative examples of the findings, rather than discuss each programme individually. It is not intended to attribute greater importance to some studies relative to others.

INSERT TABLE 1 HERE (Landscape) 


\section{Behaviour Change}

This systematic literature review included more studies that reported measuring and affecting behaviour change than other social marketing reviews (see Carins and Rundle-Thiele, 2013; Janssen et al., 2013; Truong, 2014). However, given substantial differences in outcome measures, the behaviour change results were analysed qualitatively consistent with the approach of extant literature (i.e. Carins and Rundle-Thiele, 2013; Foxcroft and Tsertsvadze, 2012). Positive behavioural outcomes were observed in both the short and medium term. Nine studies reported positive behaviour change effects (Conrod et al., 2006, 2008; D’Amico et al., 2006; Gmel et al., 2012; Hardoff et al., 2013; McBride et al., 2004; Morgenstern et al., 2009; O’Leary-Barrett et al. 2010; Vogl et al., 2009). Five of the sixteen programmes were in initial trial stages (i.e. Alcolado and Alcolado, 2011; Lammers et al., 2011; Newton et al., 2012; Rundle-Thiele et al., 2013, Will and Sabo, 2010) and long-term behavioural data was not available at the time of writing. Successful effects were observed in the two year alcohol education programme SHAHRP (McBride et al., 2000ab), with 30\% less alcohol consumption at eight and 20 month follow-up. The 18 lesson curriculum reported 23\% less harm at a 32 month follow-up, but no reduced drinking behaviour (McBride et al., 2004). Shorter and more cost effective solutions appeared in the form of brief programmes (see for example Alcolado and Alcolado, 2011; Conrod et al., 2006, 2008, 2011; Gmel et al., 2012; Hardoff et al., 2013). For example, Conrod et al. (2008) achieved six month reduced drinking and binge drinking and 24 month reduced problem drinking symptoms amongst 13-14 year old adolescents. The programme consisted of two 90 minute modules targeted to students that scored high on one of four personality risk profiles (Conrod et al., 2006, 2008, 2011). Brief programmes were effective, suggesting that for single substances, short programmes may offer a less resource intensive format to enact change. 


\section{Theory}

Previous research by Botvin and Griffin (2004, 2007), Dusenbury et al. (1997), Nation et al. (2003), Roche et al. (2010) and Stigler et al. (2011) suggests that theory application and adaption is essential to programme design. The majority of programmes in this review reported theory use in programme design $(n=13)$. The most commonly employed theories were social learning theory $(n=4)$, social norms $(n=3)$ and experiential learning theory $(n=2)$. Identical to the Foxcroft and Tsertsvadze (2012) literature review, the results of this review suggest the most commonly employed theory within this context is social learning theory, although brief alcohol education programmes designed originally by Conrod et al. (2006, 2008, 2013), and subsequently adapted by Lammers et al. (2011) and O’Leary-Barrett (2010), focused on individual rather than social influence factors. However, despite evidence of theory application in programme design, reporting surrounding theory use may not be improving. Theory application should be reported in more detail to explain how theory helped in the design of programme components. This would ensure that these insights can be utilised in future programme development. Social marketing research also provides evidence for the utility of employing theory beyond programme design in areas such as audience research, segmentation, message formation and evaluation (Truong, 2014). Further application and more detailed reporting of theory in school-based alcohol education programmes may therefore be useful.

\section{Audience Research}

Ten programmes did not report undertaking audience research and the remaining programmes (Alcolado and Alcolado, 2011; Conrod et al., 2008, 2011; D’Amico et al., 2006; Newton et al., 2012, Rundle-Thiele et al., 2013; Vogl et al., 2009, 2012) conducted limited audience research. The audience research that was undertaken largely comprised focus 
groups prior to programme implementation (Conrod et al., 2008, 2011; McBride et al., 2000b), to inform programme development (Newton et al., 2009; Vogl et al. 2009; Will and Sabo, 2010) and post programme implementation to evaluate programme satisfaction (Alcolado and Alcolado, 2011). Of all the stakeholders involved in designing an alcohol education programme, we would expect students as the primary target audience (group) to inform and/or guide programme design to a greater extent than teachers and other stakeholders. Our findings indicate the contrary and suggest only very limited student involvement.

The majority of the programmes employed an expert-driven design philosophy (e.g. Gmel et al., 2012; Hardoff et al., 2013; Morgenstern et al., 2009; Vogl et al., 2009, Will and Sabo, 2010). An expert-driven approach may include only limited research with the target audience and only little involvement in programme design. For example, Will and Sabo (2010) reported a close working relationship with school system representatives, key stakeholders in the community as well as an advisory board to inform programme design. However, students came last in this process. Only post programme development, two focus groups were conducted with students which resulted in minor programme changes. A different approach was taken by Alcolado and Alcolado (2011) where medical students designed the MEDALC programme in the UK, yet feedback was only collected from teachers and students regarding programme satisfaction. Newton and colleagues (2009) developed an online alcohol education programme, CLIMATE, for Australian high school students based primarily on expert opinions (Newton et al., 2009; Vogl, 2007). Teacher and student involvement was sought after the programme had been designed to provide feedback on programme content and wording. Similarly, McBride and colleagues (2000b) reported piloting the program and running an evaluation workshop with students and teachers post building the evidence-based 
SHAHRP programme. Further, although teachers, local service coordinators and voluntary/community sector workers were consulted in modifying an abbreviated SHAHRP programme for Ireland, consultation with students regarding the program components was not reported until a pilot trial (McKay et al., 2012a).

In summary, while participatory approaches may imply involvement of stakeholders in programme development, the results of this systematic literature review suggest stakeholder involvement remains largely limited to experts rather than the primary target audience (students). Social marketing advocates an audience-oriented approach (i.e. bottom-up philosophy), as opposed to the more expert driven, top-down approach prevalent in the alcohol education programmes included in this review. Drawing on commercial marketing literature, organisations that focus on target audience needs and wants may achieve better outcomes compared to their less audience-oriented competitors (Van Raaij and Stoelhorst, 2008). Therefore, we see the need for alcohol education programmes focussing on middle and high school students to be more target audience orientated, with greater levels of audience research and where students play a stronger role in programme design. Domegan et al. (2013) suggests cocreation, through dialogue, interaction, communication and collaboration, in programme design can ensure a more audience-oriented philosophy.

\section{Segmentation and Targeting}

None of the programmes included in this review employed segmentation according to the aforementioned criteria. The majority of programmes $(n=11)$ were universal programmes that were not targeted to groups in the school population. These findings are similar to previous research suggesting that segmentation remains largely unexamined in the context of schoolbased alcohol education programmes (Mathijssen et al., 2012). Related research suggests, however, that segmentation may have a lot to offer (Lefebvre, 2013; Mathijssen et al., 2012) 
and should be further explored in the context of alcohol education programme development. Social marketing thinking begins and ends with identification of one or more target groups (Lefebvre, 2013). For example, Deshpande and Rundle-Thiele (2011) identified unique segments by understanding the values and expectancies of American university students in relation to alcohol and Mathijssen and colleagues (2012) identified segments based upon values, attitudes, behaviour as well as socio-demographic data. The principle of market segmentation is used to identify and prioritise groups to ensure that finite resources achieve maximum impact. While targeting is employed in education and prevention science based on the understanding of a "diverse range of sociocultural environments into which prevention is likely to be delivered” (Sumnall, 2014, p.vi) and the need to cater for prevailing attitudes and social trends (Room, 2012), the social marketing benchmark criteria of segmentation has received limited attention to date in alcohol education programmes delivered and evaluated in middle and high school settings.

Segmentation and targeting are key to social marketing, encompassing the identification of homogenous subgroups and the decision to either tailor different programmes to all segments, tailor programmes to one or more selected segments, or to target one individual segment. For example, Gmel et al. (2012) segmented their student cohort based upon drinking behaviour, although no differential delivery was then pursued. Other contexts include targeting efforts, such as in the contexts of multiple-substance programmes (e.g. Kulis et al., 2005) where tailored programs were designed for different subcultures, i.e. Mexican American, European American, Multicultural, African American. Programmes have shown promising results when targeted to specific subpopulation groups based on factors including ethnicity (Kulis et al. 2005, 2007), risk (Conrod et al., 2013; Conrod et al., 2006; Newton et al., 2012) and gender (Schinke et al., 2009). However, identifying the at-risk population through an initial 
screening procedure (e.g. Conrod et al., 2006) and targeting a programme to these students still does not constitute a segmentation procedure from a social marketing perspective that seeks a systematic application of the full segmentation process (segment, target, position). Interestingly, a review of the literature indicates that the majority of school-based programmes continue to follow a one size fits all approach (Botvin and Griffin, 2007; Foxcroft and Tsertsvadze, 2012) with the dual aims of avoiding stigmatisation of students and reaching as many students as possible (Offord, 2000). These findings were supported by this systematic literature review.

It is important to acknowledge the potential ethical issues involved in segmentation and targeting, as some groups may be targeted to receive a particular social marketing programme, but others will not (Donovan and Henley, 2010). A one size fits all ('universal') approach does not assess and identify particular groups, nor does it offer alternative programmes (Newton et al., 2013). There is limited evidence for the effectiveness of universal programmes (O’Leary-Barrett et al., 2010) and a one size fits all approach may limit programme effectiveness as large numbers of the audience are likely to receive little or no benefit (Mathijssen et al., 2012; Synder et al, 2004). Tailored social marketing programmes offer greater potential for success by focusing on the most vulnerable or susceptible target audiences (Newton et al., 2013). In conclusion, we recommend that the application of the social marketing criteria of segmentation warrants further investigation in a school-based alcohol education context.

\section{Research Limitations/Implications}

This systematic literature review focussed on alcohol education programmes targeting middle and high school student populations, retrieving studies back to the Year 2000. It marks the 
first study of its kind to focus investigative attention on the application of relevant social marketing criteria (behaviour change, theory, audience research and segmentation) to existing school-based alcohol education programmes. The review demonstrates alcohol education programmes targeting middle and high school students have changed alcohol-related behaviour with varying degrees of success. The findings also show widespread application of theory in the design of school-based alcohol education programmes, with social learning theory being the most commonly utilised as per previous reviews (Foxcroft and Tsertsvadze, 2012; Stead et al. 2007). The findings of this review further highlight the majority of schoolbased programmes followed a one size fits all approach. Future research should therefore design, implement and evaluate programmes that involve the systematic application of the full segmentation process (segment, target, position) to test whether programme efficacy can be improved. Assessment of the audience research criterion suggested that of all stakeholders, students were rarely involved in actual programme design. A more student-oriented focus may offer the opportunity to enhance alcohol education programme effectiveness for middle and high school settings. That is, a more detailed understanding of different characteristics of homogenous subgroups (a result of segmentation) prior to programme development may then allow for the creation of more engaging alcohol programmes (endorsed and co-created with students of the identified segments). It is then for future research to test whether this approach leads to more effective alcohol education programme outcomes.

Nevertheless, the results must be viewed in light of the systematic literature review's limitations. A key limitation of our study stems from being unable to determine and compare the effect sizes of the programmes. More consistent outcome measures in future research evaluating alcohol education programmes targeting middle to high school students would enable meta-analyses to be conducted. This would also allow the quantitative examination of 
other potential correlates of programme effectiveness, including attrition. Further, the review’s evidence base is limited to recent English language articles published in peerreviewed journals. This review excludes grey literature reports which may contain more detailed information. Future reviews could extend their scope to non-English language publications from a broader range of sources. Finally, although we endeavoured to identify all sources of information about each of the 16 interventions, including peer-reviewed publications, intervention reports and websites; it is important to note that the analysis was limited by the information provided in those sources.

Finally, a key challenge in alcohol education centres on securing adequate funding to support programme development, delivery and evaluation. Two means exist to extend alcohol programme delivery in middle and high school settings. The current review illustrates how, for example, the Australian SHAHRP programme (McBride et al 2000 a,b) has been extended and subsequently tested in Ireland, achieving positive knowledge and attitude change. Similar efforts were observed for Conrod and colleagues’ (2006) brief personality intervention programme designed in Canada and extended to England (Conrod et al. 2008), Netherlands (Lammers et al., 2011) and most recently Australia (Barrett et al., 2014). Researchers faced with funding constraints are encouraged to collaborate and extend effective alcohol education programmes in different countries. Extension of an effective alcohol education programme into other countries offers a means to significantly reduce future development costs. To ensure longevity, it is imperative that researchers work with curriculum writers and educators to ensure that following evaluation, effective programmes are embedded into curriculum. Embedding of programmes into national or state curriculum ensures that teachers can deliver programmes thereby securing alcohol education programme sustainability. 


\section{Conclusion}

This systematic review examined contemporary (since 2000) single-substance alcohol education programmes targeting middle and high school students through a social marketing lens and found that segmentation and audience research were rarely employed by the identified programmes. Evaluation of the audience research criterion revealed, more specifically, limited evidence of student involvement in programme design. Drawing on the social marketing literature, we propose that further application of the social marketing benchmark criteria of segmentation and audience research may extend on the successes of existing school-based alcohol education programmes. The results of this review may be of interest to health educators, alcohol education programme designers and decision makers seeking to explore insights and integrate novel approaches from social marketing. 


\section{References}

Australian Institute of Health and Welfare [AIHW] (2004), "Parenting influences on adolescent alcohol use”, Australian Institute of Family Studies, Research report No. 10, available at: http://www.aifs.gov.au/institute/pubs/resreport10/alcohol.html (accessed 10 March 2014).

Alcolado, R. and Alcolado, J.C. (2011), "Medical student delivery of alcohol education to high school pupils: the MEDALC programme“, Clinical Medicine, Vol. 11 No. 5, pp. 443447.

Andreasen, A.R. (1994), "Social marketing: its definition and domain“, Journal of Public Policy \& Marketing, Vol. 13 No. 1, pp. 108-114.

Andreasen, A.R. (2002), "Marketing social marketing in the social change marketplace“, Journal of Public Policy \& Marketing, Vol. 21 No. 1, pp. 3-13.

Babor, T.F., Caetano, R., Casswell, S., Edwards, G., Giesbrecht, N., Graham, K., et al. (2010), Alcohol: No Ordinary Commodity Research and Public Policy, Oxford University Press, Oxford, UK.

Barrett, E.L., Newton, K.L., Teesson, M., Slade, T. and Conrod, P. (2014), “Adapting the personality-targeted preventure program to prevent substance use and associated harms among high-risk Australian adolescents“, Early Intervention in Psychiatry, Epub ahead of print.

Botvin, G.J. and Griffin, K.W. (2007), "School-based programmes to prevent alcohol, tobacco and other drug use“, International Review of Psychiatry, Vol. 19 No. 6, pp. 607-615.

Botvin, G.J. and Griffin, K.W. (2004), "Life skills training: empirical findings and future directions“, Journal of Primary Prevention, Vol. 25 No. 2, pp. 211-232.

Brown, S. (2001), "Facilitating change for adolescent alcohol problems: a multiple options approach”, in Wagner, E. F. and Waldron, H.B. (Eds.), Innovations in Adolescent Substance Abuse Interventions, Elsevier Science, Oxford, UK, pp. 169-187.

Brown, S.A., Anderson, K.G., Schulte, M.T., Sintov, N.D. and Frissell, K.C. (2005), "Facilitating youth self-change through school-based intervention", Addictive Behaviors, Vol. 30 No. 9, pp. 1797-1810.

Carins, J.E. and Rundle-Thiele, S.R. (2013), "Eating for the better: a social marketing review (2000-2012)”, Public Health Nutrition, pp. 1-12.

Conrod, P., O'Leary-Barrett, M., Newton, N.C., Topper, L.R., Castellanos, N., Mackie, C. and Girard, A. (2013), "Effectiveness of a selective, personality-targeted prevention program for adolescent alcohol use and misuse“, JAMA psychiatry, Vol. 70 No. 3, pp. 334-342.

Conrod, P.J., Castellanos-Ryan, N. and Mackie, C. (2011), “Long-term effects of a personality-targeted intervention to reduce alcohol use in adolescents“, Journal of Consulting and Clinical Psychology, Vol. 79 No. 3, pp. 296-306. 
Conrod, P., Castellanos, N. and Mackie, C. (2008), "Personality-targeted interventions delay the growth of adolescent drinking and binge drinking“, The Journal of Child Psychology and Psychiatry, Vol. 49 No. 2, pp. 181-190.

Conrod, P.J., Stewart, S.H., Comeau, N. and Maclean, A. (2006), “efficacy of cognitivebehavioral interventions targeting personality risk factors for youth alcohol misuse“, Journal of Clinical Child and Adolescent Psychology, Vol. 35 No. 4, pp. 550-563.

Cuijpers, P. (2002), "Effective ingredients of school-based drug prevention programs: a systematic review“, Addictive Behaviors, Vol. 27 No. 6, pp. 1009-1023.

D'Amico, E.J., Anderson, K.G., Metrik, J., Frissell, K.C., Ellingstad, T. and Brown, S.A. (2006), “Adolescent self-selection of service formats: implications for secondary interventions targeting alcohol use“, American Journal on Addictions, Vol. 15 No. 1, pp. 5866.

Deshpande, S. and Rundle-Thiele, S. (2011), “Segmenting and targeting american university students to promote responsible alcohol use: a case for applying social marketing principles“, Health Marketing Quarterly, Vol. 28 No. 4, pp. 287-303.

Domegan, C., Collins, K., Stead, M., McHugh, P. and Hughes, T. (2013), "Value co-creation in social marketing: functional or fanciful“, Journal of Social Marketing, Vol. 3 No. 3, pp. 239-256.

Donovan, R. and Henley, N. (2010), Principles and Practice of Social Marketing: An International Perspective, Cambridge University Press, UK.

Dusenbury, L., Falco, M. and Lake, A. (1997), “A review of the evaluation of 47 drug abuse prevention curricula available nationally“, The Journal of School Health, Vol. 67 No. 4, pp. 125-132.

Ellickson, P.L., Tucker, J.S. and Klein, D.J. (2003), “Ten-year prospective study of public health problems associated with early drinking“, Pediatrics, Vol. 111 No. 5, pp. 949-955.

Elliott, G., Rundle-Thiele, S. and Waller, D. (2012), Marketing, Volume. 2., John Wiley \& Sons, Brisbane, Australia.

Flay, B.R. (2000), “Approaches to substance use prevention utilizing school curriculum plus environment change“, Addictive Behaviors, Vol. 25 No. 6, pp. 861-885.

Foxcroft, D.R. and Tsertsvadze A. (2012), "Universal school-based prevention programs for alcohol misuse in young people (review)“, Evidence-Based Child Health: A Cochrane Review Journal, Vol. 7 No.2, pp. 450-575.

Foxcroft, D. R., Ireland, D., Lister-Sharp, D. J., Lowe, G. and Breen, R. (2003), "Primary prevention for alcohol misuse in young people", Cochrane Database of Systematic Reviews 2002, No. 3, pp. 1-81. 
French, J. and Blair-Stevens, C. (2006). "Social marketing national benchmark criteria“, UK National Social Marketing Centre, available at: http://www.snh.org.uk/pdfs/sgp/A328466.pdf (accessed 10 January 2014).

Glider, P., Midyett, S.J., Mills-Novoa, B., Johannessen, K. and Collins, C. (2001), "Challenging the collegiate rite of passage: A campus-wide social marketing media campaign to reduce binge drinking”, Journal of Drug Education, Vol. 31 No. 2, pp. 207-220.

Glik, D., Prelip, M., Myerson, A. and Eilers, K. (2008), "Fetal alcohol syndrome prevention using community-based narrowcasting campaigns”, Health Promotion Practice, Vol. 9 No. 1, pp. 93-103.

Gmel, G., Venzin, V., Marmet, K., Danko, G. and Labhart, F. (2012), “A quasi-randomized group trial of a brief alcohol intervention on risky single occasion drinking among secondary school students”, International Journal of Public Health, Vol. 57 No. 6, pp. 935-944.

Goetzel, R.Z. (2009), "Do prevention or treatment services save money? The wrong debate”, Health Affairs, Vol. 28 No. 1, pp. 37-41.

Gomberg, L., Shari Kessel, S. and DeJong, W. (2001), "Evaluation of a social norms marketing campaign to reduce high-risk drinking at the university of mississippi“, The American Journal of Drug and Alcohol Abuse, Vol. 27 No. 2, pp. 375-389.

Gordon, R., McDermott, L., Stead, M. and Angus, K. (2006), “The effectiveness of social marketing interventions for health improvement: what's the evidence? “, Public Health, Vol. 120 No. 12, pp. 1133-1139.

Gracia-Marco, L., Vicente-Rodriguez, G., Borys, J.M., Le Bodo, Y., Pettigrew, S. and Moreno, L.A. (2011), "Contribution of social marketing strategies to community-based obesity prevention programmes in children“, International Journal of Obesity, Vol. 35, pp. 472-479.

Hardoff, D., Stoffman, N. and Ziv, A. (2013), "Empowering adolescents to control alcoholassociated risky situations“, Archives of Disease in Childhood, Vol. 98 No. 9, pp. 672-675.

Hastings, G., Stead, M. and MacKintosh, A. (2002), "Rethinking drugs prevention: radical thoughts from social marketing“, Health Education, Vol. 61 No. 4, pp. 347-364.

Janssen, M., Mathijssen, J., van Bon-Martens, M., van Oers, H. and Garretsen, H. (2013), "Effectiveness of alcohol prevention interventions based on the principles of social marketing: a systematic review“, Substance Abuse Treatment, Prevention, and Policy, Vol. 8 No. 18, pp. 1-11.

Kotler, P. and Armstrong, G. (2001), Principles of Marketing, 9th ed., Prentice Hall, Upper Saddle River, N.J.

Kulis, S., Yabiku, S., Marsiglia, F., Nieri, T. and Crossman, A. (2007), “Differences by gender, ethnicity, and acculturation in the efficacy of the keepin' it real model prevention program“, Journal of Drug Education, Vol. 37 No. 2, pp. 123-144. 
Kulis, S., Marsiglia, F.F., Elek, E., Dustman, P., Wagstaff, D.A. and Hecht, M.L. (2005), "Mexican/mexican american adolescents and keepin' it real: an evidence based substance abuse prevention program”, Children \& Schools, Vol. 27 No. 3, pp. 133-145.

Kypri, K. and Dean, J.I. (2002), “The should you supply community alcohol intervention: an evaluation for the alcohol advisory council of New Zealand”, Alcohol Advisory Council of New Zealand“, ALAC Occasional Publication, New Zealand.

Kypri, K., Dean, J., Kirby, S., Harris, J. and Kake, T. (2005), “Think before you buy under18s drink: evaluation of a community alcohol intervention“, Drug and Alcohol Review, Vol. 24 No. 1, pp. 13-20.

Lammers, J., Goossens, F., Lokman, S., Monshouwer, K., Lemmers, L., Conrod, P., Wiers, R., Engels, R. and Kleinjan, M. (2011), "Evaluating a selective prevention programme for binge drinking among young adolescents: study protocol of a randomized controlled trial”, BMC Public Health, Vol. 11, pp. 126-126.

Lee, N.R. and Kotler, P. (2011), Social Marketing Influencing Behaviors for Good, 4th ed., Sage Publications, Thousand Oaks, California, USA.

Lefebvre, R.C. (2013), Social Marketing and Social Change: Strategies and Tools for Improving Health, Well-being and the Environment, Jossey-Bass, San Francisco, USA.

Lloyd, C., Joyce, R., Hurry, J. and Ashton, M. (2000), “The effectiveness of primary school drug education”, Drugs-Education Prevention and Policy, Vol. 7 No. 2, pp. 109-126.

Martinus, T., Melson, A.J., Davies, J.B. and McLaughlin, A. (2012), “The 'social norms' approach to alcohol misuse prevention: testing transferability in a Scottish secondary school context“, Drugs-Education Prevention and Policy, Vol. 19 No. 2, pp. 111-119.

Mathijssen, J., Janssen, M., van Bon-Martens, M. and van de Goor, I. (2012), “Adolescents and alcohol: an explorative audience segmentation analysis“, BMC Public Health, Vol. 12 No. 742, pp. 1-10.

McBride, N., Farringdon, F. and Midford, R. (2000a), "What harms do young Australians experience in alcohol-use situations“, Australian \& New Zealand Journal of Public Health, Vol. 24 No. 1, pp. 54-59.

McBride, N., Midford, R., Farringdon, F. and Phillips, M. (2000b), "Early results from a school alcohol harm minimization study: the school health and alcohol harm reduction project“, Addiction, Vol. 95 No. 7, pp. 1021-1042.

McBride, N. (2003), "A systematic review of school drug education“, Health Education Research, Vol. 18 No. 6, pp. 729-742.

McBride, N., Farringdon, F., Midford, R., Meuleners, L. and Phillips, M. (2003), “Early unsupervised drinking - reducing the risks. The school health and alcohol harm reduction project“, Drug and Alcohol Review, Vol. 22 No. 3, pp. 263-276. 
McBride, N., Farringdon, F., Midford, R., Meuleners, L. and Phillips, M. (2004), "Harm minimization in school drug education: final results of the school health and alcohol harm reduction project (SHAHRP) “, Addiction, Vol. 99 No. 3, pp. 278-291.

McBride, N., Farringdon, F. and Kennedy, C. (2007), "Research to practice - formal dissemination of the school health and alcohol harm reduction project (SHAHRP) in Australia“, Drug \& Alcohol Review, Vol. 26 No. 6, pp. 665-672.

McKay, M.T., McBride, N.T., Sumnall, H.R. and Cole, J.C. (2012a), "Reducing the harm from adolescent alcohol consumption: results from an adapted version of SHAHRP in Northern Ireland“, Journal of Substance Use, Vol. 17 No. 2, pp. 98-121.

McKay, M.T., Ballantyne, N., Goudie, A.J., Sumnall, H.R. and Cole, J.C. (2012b), "Here for a good time, not a long time: decision-making, future consequences and alcohol use among Northern Irish adolescents”, Journal of Substance Use, Vol. 17 No. 1, pp. 1-18.

McKay, M.T., Cole, J.C. and Sumnall, H.R. (2011a), “Teenage thinking on teenage drinking: 15- to 16-year olds' experiences of alcohol in Northern Ireland“, Drugs-Education Prevention and Policy, Vol. 18 No. 5, pp. 323-332.

McKay, M.T., Sumnall, H.R., Goudie, A.J., Field, M. and Cole, J.C. (2011b), "What differentiates adolescent problematic drinkers from their peers? Results from a cross sectional study in Northern Irish school children", Drugs: education, prevention and policy, Vol. 18 No. 3, pp. 187-197.

Melson, A.J., Davies, J.B. and Martinus, T. (2011), “Overestimation of peer drinking: error of judgement or methodological artefact? “, Addiciton, Vol. 106, pp. 1078-1084.

Moher, D., Liberati, A., Tetzlaff, J. and Altman, D. (2009), "Preferred Reporting Items for Systematic Reviews and Meta-Analyses: The PRISMA Statement“, Journal of Clinical Epidemiology, Vol. 62, pp. 1006-1012.

Morgenstern, M., Wiborg, G., Isensee, B. and Hanewinkel, R. (2009), "School-based alcohol education: results of a cluster-randomized controlled trial“, Addiction, Vol. 104 No. 3, pp. 402-412.

Nation, M., Crusto, C., Wandersman, A., Kumpfer, K.L., Seybolt, D., Morrisey-Kane, E. and Davino, K. (2003), "What works in prevention; principles of effective prevention programs“, American Psychologist, Vol. 58, pp. 449-456.

Newton, J.D., Newton, F.J., Turk, T. and Ewing, M.T. (2013), “Ethical evaluation of audience segmentation in social marketing“, European Journal of Marketing, Vol. 47 No. 9, pp. 1421-1438.

Newton, N.C., Teesson, M., Barrett, E.L., Slade, T. and Conrod, P.J. (2012), “The CAP study, evaluation of integrated universal and selective prevention strategies for youth alcohol misuse: study protocol of a cluster randomized controlled trial“, BMC Psychiatry, Vol. 12, pp. 118-118. 
Newton, N.C., Vogl, L., Teesson, M. and Andrews, G. (2009), “CLIMATE schools: alcohol module: cross-validation of a school-based prevention programme for alcohol misuse“, Australian \& New Zealand Journal of Psychiatry, Vol. 43, pp. 201-207.

National Health and Medical Research Council [NHMRC] (2009), “Australian guidelines to reduce health risks from drinking alcohol“", Canberra, Australia, available at:

http://www.nhmrc.gov.au/_files_nhmrc/publications/attachments/ds10-alcohol.pdf (accessed 08 January 2014).

National Preventative Health Task Force [NPHTF] (2008), "Preventing alcohol-related harm in Australia: a window of opportunity“, National Preventative Health Task Force, Australia, available at: http://www.health.gov.au/internet/ preventativehealth/publishing.nsf/ Content/09C94C0F1B9799F5CA2574DD0081E770/\$File/alcohol-jul09.pdf (accessed 08 January 2014).

Offord, D.R. (2000), "Selection of levels of prevention“, Addictive Behaviors, Vol. 26 No. 6, pp. 833-842.

O'Leary-Barrett, M., Mackie, C.J., Castellanos-Ryan, N., Al-Khudhairy, N. and Conrod, P.J. (2010), "Personality-targeted interventions delay uptake of drinking and decrease risk of alcohol-related problems when delivered by teachers", Journal of the American Academy of Child and Adolescent Psychiatry, Vol. 49 No. 9, pp. 954-963.

Payne, J.M., France, K.E., Henley, N., D'Antoine, H.A., Bartu, A.E., Mutch, R.C. and Bower, C. (2011), "Paediatricians' knowledge, attitudes and practice following provision of educational resources about prevention of prenatal alcohol exposure and Fetal Alcohol Spectrum Disorder“, Journal of Paediatrics and Child Health, Vol. 47 No. 10, pp. 704-710.

Roche, A., Bywood, P., Hughes, C., Freeman, T., Duraisingam, V., Trifonoff, A., Tovell, A. and Steenson, T. (2010), "The Role of Schools in Alcohol Education - Final Report to the: Australian Government Department of Education, Employment and Workplace Relations“, National Centre for Education and Training on Addiction [NCETA], Australia, available at: http://nceta.flinders.edu.au/files/6313/5544/7032/EN436_Roche_et_al_2010.pdf (accessed 08 January 2014).

Room, R. (2012), "Preventing youthful substance use and harm--between effectiveness and political wishfulness“, Substance Use and Misuse, Vol. 47 No. 8-9, pp. 936-943.

Rothschild, M.L., Mastin, B. and Miller, T.W. (2006), "Reducing alcohol-impaired driving crashes through the use of social marketing", Accident Analysis and Prevention, Vol. 38 No. 6, pp. 1218-1230.

Rothschild, M. (1999), "Carrots, sticks, and promises: a conceptual framework for the management of public health and social issue behaviors", The Journal of Marketing, Vol. 63 No. 4, pp. 24-37.

Rowland, B., Toumbourou, J.W., Osborn, A., Smith, R., Hall, J.K., Kremer, P., Kelly, A.B., Williams, J. and Leslie, E. (2013), “A clustered randomised trial examining the effect of social marketing and community mobilisation on the age of uptake and levels of alcohol consumption by Australian adolescents“, BMJ Open, Vol. 3 No. 1, pp. 1-8. 
Rundle-Thiele, S.R., Russell-Bennett, R., Leo, C. and Dietrich, T. (2013), "Moderating teen drinking: combining social marketing and education“, Health Education, Vol. 113 No. 5, pp. 392-406.

Schinke, S.P., Cole, K.C.A. and Fang, L. (2009), “Gender-specific intervention to reduce underage drinking among early adolescent girls: a test of a computer-mediated, motherdaughter program“, Journal of Studies on Alcohol and Drugs, Vol. 70 No. 1, pp. 70-77.

Shanahan, P., Wilkins, M. and Hurt, N. (2002), "National alcohol strategy 2001 to 2003-04”, Research and Marketing Group Population Health Division, Australia.

Slater, M.D., Kelly, K.J., Edwards, R.W., Thurman, P.J., Plested, B.A., Keefe, T.J., Lawrence, F.R. and Henry, K.L. (2006), "Combining in-school and community-based media efforts: reducing marijuana and alcohol uptake among younger adolescents“, Health Education Research, Vol. 21 No. 1, pp. 157-167.

Squeglia, L.M., Jacobus, J. and Tapert, S.F. (2009), “The influence of substance use on adolescent brain development“, Clinical EEG and Neuroscience, Vol. 40 No. 1, pp. 3138.

Stead, M., Gordon, R., Angus, K. and McDermott, L. (2007), “A systematic review of social marketing effectiveness”, Health Education, Vol. 107 No. 2, pp. 126-191.

Stigler, M.H., Neusel, E. and Perry, C. (2011), “School-based programs to prevent and reduce alcohol use among youth“, Alcohol Research \& Health, Vol. 34 No. 2, pp. 157-162.

Sumnall, H. (2014), "Prevention science: a global issue”, in Sloboda, Z. and Petras, H. (Eds.), Defining Prevention Science, Springer, New York, NY, pp v-viii.

Snyder, L., Hamilton, M., Mitchell, E., Kiwanuka-Tondo, J., Fleming-Milici, F. and Proctor, D. (2004), "A meta-analysis of the effect of mediated health communication campaigns on behavior change in the United States“, Journal of Health Communication, Vol. 9 No. 1, pp. 71-96.

Teesson, M., Newton, N. and Barrett, E. (2012), “Australian school-based prevention programs for alcohol and other drugs: a systematic review“, Drug and Alcohol Review, pp 16.

Tobler, N.S. and Stratton, H.H. (1997), "Effectiveness of school-based drug prevention programs: a meta-analysis of the research“, The Journal of Primary Prevention, Vol. 18 No. 1, pp. 71-128.

Truong, V.D. (2014), "Social marketing: a systematic review of research 1998-2012“, Social Marketing Quarterly, Vol. 20 No. 1, pp. 15-34.

Van Raaij, E.M. and Stoelhorst, J. (2008). “The implementation of a market orientation: A review and integration of the contributions to date“, European Journal of Marketing, Vol. 42 No. 11/12, pp. 1265-1293. 
Vinci, D.M., Philen, R.C., Walch, S.E., Kennedy, R., Harrell, M., Rime, C. and Matthews, J. (2010), "Social norms tactics to promote a campus alcohol coalition", American Journal of Health Education, Vol. 41 No. 1, pp. 29-37.

Vogl, L., Teesson, M., Newton, K.L. and Andrews, G. (2012), “Developing a school-based drug prevention program to overcome barriers to effective program implementation: the CLIMATE schools: alcohol module“, Open Journal of Preventive Medicine, Vol. 2 No. 3, pp. 410-422.

Vogl, L., Teesson, M., Andrews, G., Bird, K., Steadman, B. and Dillon, P. (2009), “A computerized harm minimization prevention program for alcohol misuse and related harms: randomized controlled trial“, Addiction, Vol. 104 No. 4, pp. 564-575.

Vogl, L. (2007), “CLIMATE schools: alcohol module - the feasibility and efficacy of a universal school-based computerised prevention program for alcohol misuse and related harms“, (Doctor of Philosophy), University of Sydney, Australia.

White, D. and Pitts, M. (1998), "Educating young people about drugs: a systematic review“, Addiction, Vol. 93 No. 10, pp. 1475-1487.

Will, K.E. and Sabo, C.S. (2010), "Reinforcing alcohol prevention (RAP) program: a secondary school curriculum to combat underage drinking and impaired driving“, Journal of Alcohol and Drug Education, Vol. 54 No. 1, pp. 14-36. 
Figure 1 - Flowchart of Systematic Literature Review

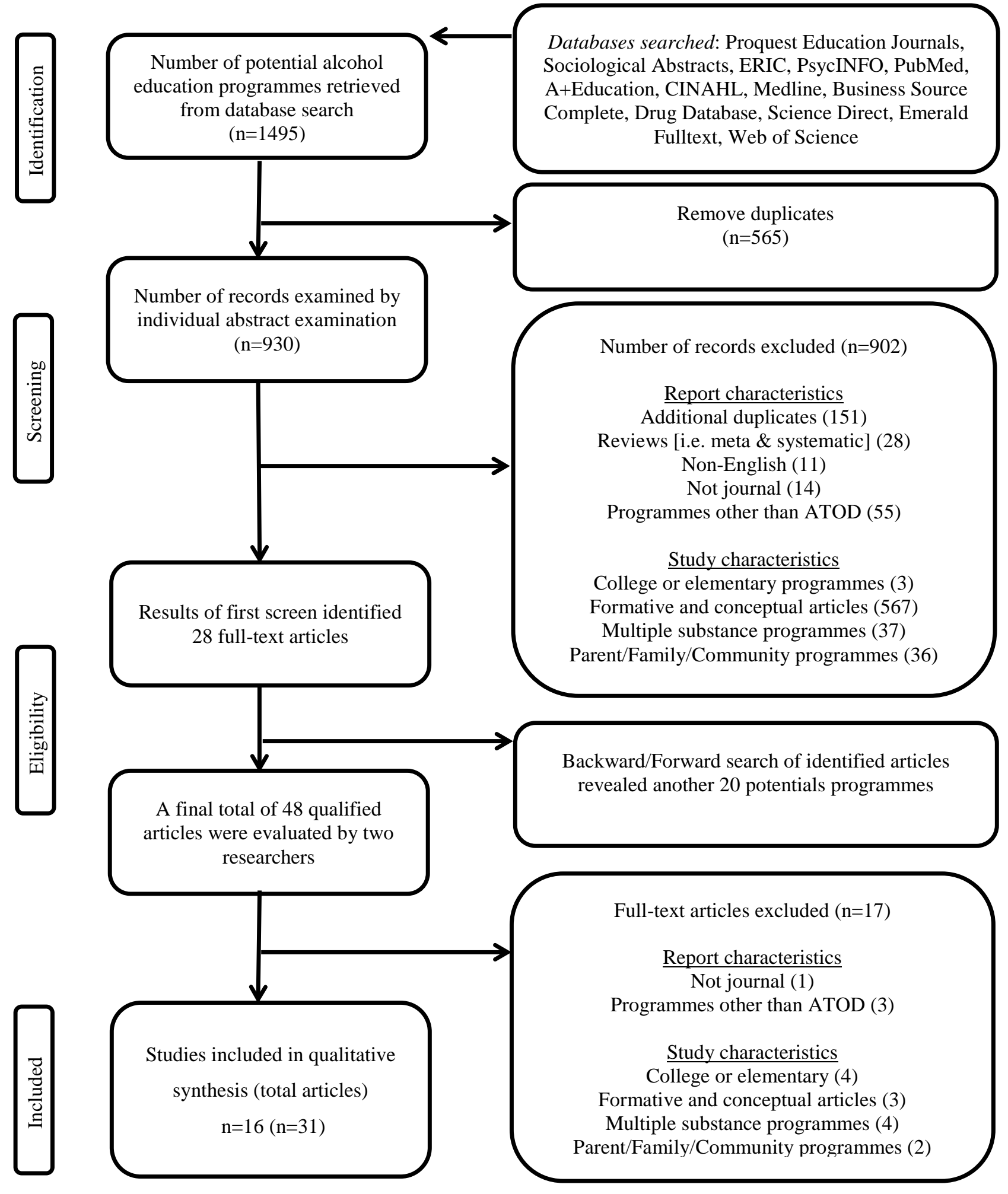


Table 1 - Overview of Programmes

\begin{tabular}{|c|c|c|c|c|c|c|c|c|c|c|c|}
\hline & 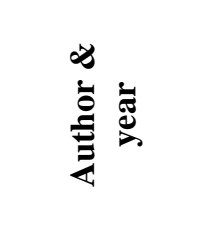 & 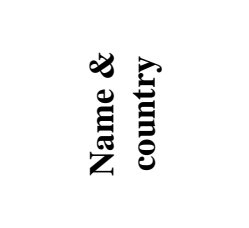 & 范 & 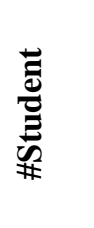 & 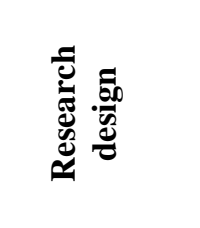 & 壱 品 & 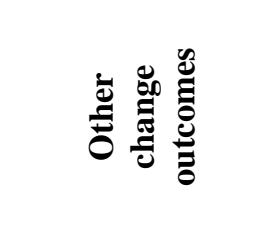 & 总 & 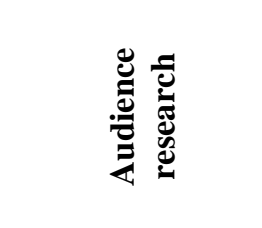 & 苛 & 葛 \\
\hline 1 & $\begin{array}{c}\text { McBride et } \\
\text { al. (2000ab, } \\
\text { 2003, 2004, } \\
\text { 2007) }\end{array}$ & $\begin{array}{c}\text { SHAHRP } \\
\text { Perth, Australia }\end{array}$ & $13-17$ & 2343 & $\begin{array}{c}\text { Quasi- } \\
\text { experimental } \\
\text { control } \\
\text { design }\end{array}$ & $\begin{array}{l}30 \% \text { less } \\
\text { alcohol } \\
\text { consumption at } \\
8 \& 20 \mathrm{~m} \\
\text { follow-up. } \\
23 \% \text { less } \\
\text { reported harm } \\
\text { (at 32m) }\end{array}$ & $\begin{array}{l}\text { Higher knowledge } \\
\text { \& safer alcohol } \\
\text { attitudes with } \\
\text { positive effect till } \\
\text { 20m follow up }\end{array}$ & Not reported & $\begin{array}{l}\text { Focus groups, } \\
\text { insights were } \\
\text { generated before } \\
\text { programme } \\
\text { development (11- } \\
\text { 12y), } 3 \text { schools } \\
\text { piloted } \\
\text { programme / } \\
\text { Evaluation } \\
\text { workshop to } \\
\text { assess materials }\end{array}$ & No & $\begin{array}{l}\text { Universal } \\
\text { programme }\end{array}$ \\
\hline 2 & $\begin{array}{l}\text { Conrod et al. } \\
\text { (2006) }\end{array}$ & $\begin{array}{c}\text { Brief } \\
\text { Personality } \\
\text { intervention, } \\
\text { Canada } \\
\end{array}$ & $14-17$ & 297 & RCT & $\begin{array}{c}\text { Reduced } \\
\text { drinking at } 4 \mathrm{~m} \\
\text { follow-up }\end{array}$ & Not reported & $\begin{array}{c}\text { Individual risk } \\
\text { factors for } \\
\text { adolescents }\end{array}$ & Not reported & No & $\begin{array}{l}\text { Targeted } \\
\text { high-risk } \\
\text { teenagers }\end{array}$ \\
\hline 3 & $\begin{array}{l}\text { D’Amico et } \\
\text { al. (2006), } \\
\text { Brown et al. } \\
\text { (2005), } \\
\text { Brown } \\
\text { (2001) }\end{array}$ & $\begin{array}{c}\text { Project Options, } \\
\text { USA }\end{array}$ & $13-18$ & 1254 & $\begin{array}{l}\text { Voluntary } \\
\text { programme } \\
\text { no RCT }\end{array}$ & $\begin{array}{c}\text { Lower } \\
\text { proportions } \\
\text { and intensity } \\
\text { of drinking }\end{array}$ & Not reported & $\begin{array}{c}\text { Developmental } \\
\text { social } \\
\text { information } \\
\text { processing } \\
\text { model \& } \\
\text { normative } \\
\text { education }\end{array}$ & $\begin{array}{l}\text { Youth } \\
\text { involvement in } \\
\text { programme } \\
\text { design. Students } \\
\text { were allowed to } \\
\text { choose whether } \\
\text { they wanted to } \\
\text { enter group or } \\
\text { individual format }\end{array}$ & No & $\begin{array}{c}\text { Universal } \\
\text { programme }\end{array}$ \\
\hline 4 & $\begin{array}{l}\text { Conrod et al. } \\
\text { (2008; 2011) }\end{array}$ & $\begin{array}{c}\text { Personality- } \\
\text { targeted } \\
\text { interventions, } \\
\text { UK }\end{array}$ & $13-14$ & 2676 & RCT & $\begin{array}{c}\text { Reduced } \\
\text { drinking and } \\
\text { binge drinking } \\
\text { levels at } 6 \mathrm{~m}\end{array}$ & Not reported & $\begin{array}{l}\text { Individual risk } \\
\text { factors for } \\
\text { adolescents }\end{array}$ & $\begin{array}{l}\text { Real life } \\
\text { experiences from } \\
\text { high personality } \\
\text { risk UK youth in } \\
\text { focus group } \\
\text { sessions }\end{array}$ & No & $\begin{array}{l}\text { Targeted } \\
\text { high-risk } \\
\text { teenagers }\end{array}$ \\
\hline
\end{tabular}




\begin{tabular}{|c|c|c|c|c|c|c|c|c|c|c|c|}
\hline 5 & $\begin{array}{l}\text { Morgenstern } \\
\text { et al. (2009) }\end{array}$ & $\begin{array}{l}\text { No name, } \\
\text { Germany }\end{array}$ & $12-15$ & 1686 & Cluster RCT & $\begin{array}{l}\text { Less binge } \\
\text { drinking }\end{array}$ & $\begin{array}{l}\text { Higher knowledge, } \\
\text { no effects on } \\
\text { attitudes, intentions }\end{array}$ & $\begin{array}{l}\text { Social influence } \\
\text { approach }\end{array}$ & Not reported & No & $\begin{array}{c}\text { Universal } \\
\text { programme }\end{array}$ \\
\hline 6 & $\begin{array}{c}\text { Vogl et al. } \\
\text { (2009; 2012), } \\
\text { Newton et al. } \\
\text { (2009) }\end{array}$ & $\begin{array}{l}\text { CLIMATE } \\
\text { Alcohol } \\
\text { module, } \\
\text { Australia }\end{array}$ & $\begin{array}{c}13 \\
(\operatorname{avg})\end{array}$ & 1466 & RCT & $\begin{array}{l}\text { Less binge } \\
\text { drinking by } \\
\text { girls }\end{array}$ & $\begin{array}{l}\text { Increased } \\
\text { knowledge \& } \\
\text { reduced } \\
\text { expectancies }\end{array}$ & $\begin{array}{c}\text { Social influence } \\
\text { approach }\end{array}$ & $\begin{array}{l}\text { Teacher and } \\
\text { student feedback } \\
\text { was sought after } \\
\text { the programme } \\
\text { had been designed }\end{array}$ & No & $\begin{array}{c}\text { Universal } \\
\text { programme }\end{array}$ \\
\hline 7 & $\begin{array}{l}\text { Will \& Sabo } \\
\text { (2010) }\end{array}$ & $\begin{array}{l}\text { Reinforcing } \\
\text { Alcohol } \\
\text { Prevention } \\
\text { (RAP), USA }\end{array}$ & $13-16$ & 1720 & $\begin{array}{l}\text { Pilot study } \\
\text { (no control) } \\
-4 \text { schools }\end{array}$ & Not reported & $\begin{array}{l}\text { Knowledge } \\
\text { increase }\end{array}$ & $\begin{array}{c}\text { Social cognitive } \\
\text { theory (SCT) \& } \\
\text { normative } \\
\text { education }\end{array}$ & $\begin{array}{l}\text { School system } \\
\text { representatives, } \\
\text { key stakeholders } \\
\text { in the community, } \\
\text { advisory board. } 2 \\
\text { Focus groups post } \\
\text { programme } \\
\text { development. }\end{array}$ & No & $\begin{array}{c}\text { Universal } \\
\text { programme }\end{array}$ \\
\hline 8 & $\begin{array}{l}\text { O’Leary- } \\
\text { Barrett et al. } \\
\text { (2010); } \\
\text { Conrod et al. } \\
\text { (2013) }\end{array}$ & $\begin{array}{c}\text { Adventure Trial, } \\
\text { UK }\end{array}$ & $12-15$ & 2650 & RCT & $\begin{array}{l}\text { Lower } \\
\text { drinking and } \\
\text { binge drinking } \\
\text { rates at } 6 \mathrm{~m} \\
\text { follow-up }\end{array}$ & Not reported & $\begin{array}{l}\text { Individual risk } \\
\text { factors for } \\
\text { adolescents }\end{array}$ & Not reported & No & $\begin{array}{l}\text { Targeted } \\
\text { high-risk } \\
\text { teenagers }\end{array}$ \\
\hline 9 & $\begin{array}{l}\text { Alcolado \& } \\
\text { Alcolado } \\
\text { (2011) }\end{array}$ & $\begin{array}{l}\text { MEDALC, } \\
\text { UK }\end{array}$ & $13-15$ & 1780 & $\begin{array}{l}\text { Pilot study } \\
\text { (no control) }\end{array}$ & Not reported & Higher knowledge & Not reported & $\begin{array}{l}\text { Medical students } \\
\text { designed } \\
\text { programme. } \\
\text { Student \& teacher } \\
\text { feedback, as well } \\
\text { as } 1500 \text { word } \\
\text { report by medical } \\
\text { students was } \\
\text { collected post } \\
\text { programme } \\
\text { development }\end{array}$ & No & $\begin{array}{c}\text { Universal } \\
\text { programme }\end{array}$ \\
\hline 10 & $\begin{array}{l}\text { Lammers et } \\
\text { al (2011) }\end{array}$ & $\begin{array}{l}\text { Preventure, } \\
\text { Netherlands }\end{array}$ & $13-15$ & 5057 & RCT & Not reported & $\begin{array}{l}\text { To be reported in } \\
\text { later studies }\end{array}$ & $\begin{array}{l}\text { Individual risk } \\
\text { factors for } \\
\text { adolescents } \\
\end{array}$ & $\begin{array}{l}\text { Preventure } \\
\text { programme } \\
\text { adapted from } \\
\text { Conrod et al. }\end{array}$ & No & $\begin{array}{l}\text { Targeted } \\
\text { high-risk } \\
\text { teenagers }\end{array}$ \\
\hline
\end{tabular}




\begin{tabular}{|c|c|c|c|c|c|c|c|c|c|c|c|}
\hline & & & & & & & & & $\begin{array}{l}\text { (2006), tailored to } \\
\text { Canadian context }\end{array}$ & & \\
\hline 11 & $\begin{array}{l}\text { McKay et al. } \\
\text { ( 2011ab; } \\
\text { 2012ab) }\end{array}$ & $\begin{array}{l}\text { SHAHRP, } \\
\text { Northern } \\
\text { Ireland }\end{array}$ & $13-15$ & 2349 & $\begin{array}{l}\text { Controlled } \\
\text { non- } \\
\text { randomised } \\
\text { trial }\end{array}$ & $\begin{array}{c}\text { No behaviour } \\
\text { change } \\
\text { observed at } \\
\text { 12m follow-up }\end{array}$ & $\begin{array}{l}\text { Knowledge } \\
\text { increase. No } \\
\text { attitude change }\end{array}$ & Not reported & Not reported & No & $\begin{array}{c}\text { Universal } \\
\text { programme }\end{array}$ \\
\hline 12 & $\begin{array}{l}\text { Melson et al. } \\
\text { (2011); } \\
\text { Martinus et } \\
\text { al. (2012) }\end{array}$ & $\begin{array}{l}\text { Social Norms', } \\
\text { Central } \\
\text { Scotland }\end{array}$ & 14 & 686 & $\begin{array}{c}3 \text { year } \\
\text { control case } \\
\text { study }\end{array}$ & $\begin{array}{l}\text { Only reported } \\
\text { baseline } \\
\text { findings, no } \\
\text { change effects }\end{array}$ & $\begin{array}{c}\text { Only reported } \\
\text { baseline findings, } \\
\text { no change effects }\end{array}$ & $\begin{array}{l}\text { Social Norms } \\
\text { approach }\end{array}$ & Not reported & No & $\begin{array}{c}\text { Universal } \\
\text { programme }\end{array}$ \\
\hline 13 & $\begin{array}{l}\text { Gmel et al. } \\
\text { (2012) }\end{array}$ & $\begin{array}{l}\text { No name, } \\
\text { Zuerich } \\
\text { Switzwerland }\end{array}$ & $16-18$ & 686 & $\begin{array}{c}\text { Cluster } \\
\text { quasi-RCT }\end{array}$ & $\begin{array}{l}\text { Reduced heavy } \\
\text { drinking and } \\
\text { drinking } \\
\text { occasions in } \\
\text { medium-risk } \\
\text { group. } \\
\text { Ineffective for } \\
\text { all at risk users }\end{array}$ & Not reported & Not reported & Not reported & No & $\begin{array}{c}\text { Universal } \\
\text { programme }\end{array}$ \\
\hline 14 & $\begin{array}{l}\text { Newton et al. } \\
\text { (2012), } \\
\text { Barrett et al. } \\
\text { (2014) }\end{array}$ & $\begin{array}{l}\text { CAP study, } \\
\text { Australia }\end{array}$ & $13-14$ & $\begin{array}{l}\text { Not re- } \\
\text { ported }\end{array}$ & RCT & Not reported & Not reported & $\begin{array}{c}\text { Preventure: } \\
\text { Design based on } \\
\text { personality risk } \\
\text { factors } \\
\text { Climate: Social } \\
\text { influence } \\
\text { approach }\end{array}$ & $\begin{array}{l}\text { Preventure } \\
\text { programme } \\
\text { adapted from } \\
\text { Conrod et al. } \\
\text { (2006), tailored to } \\
\text { Australian context } \\
\text { CLIMATE see } \\
\text { Vogl et al. (2009) }\end{array}$ & No & $\begin{array}{l}\text { Targeted } \\
\text { high-risk } \\
\text { teenagers }\end{array}$ \\
\hline 15 & $\begin{array}{l}\text { Rundle- } \\
\text { Thiele et al. } \\
\text { (2013) }\end{array}$ & $\begin{array}{c}\text { GO:KA } \\
\text { QLD, Australia }\end{array}$ & $14-16$ & 223 & $\begin{array}{l}\text { Pre Post } \\
\text { design (pilot } \\
\text { study, no } \\
\text { control) }\end{array}$ & Not reported & $\begin{array}{l}\text { Knowledge } \\
\text { increase, attitude } \\
\text { and intention } \\
\text { change reported }\end{array}$ & $\begin{array}{c}\text { Theory of } \\
\text { planned } \\
\text { behaviour; } \\
\text { Social } \\
\text { marketing } \\
\text { principles \& } \\
\text { experiential } \\
\text { learning }\end{array}$ & $\begin{array}{l}\text { Focus groups, } \\
\text { ethnographic } \\
\text { research, } \\
\text { satisfaction with } \\
\text { online games and } \\
\text { practical activities }\end{array}$ & No & $\begin{array}{c}\text { Universal } \\
\text { programme }\end{array}$ \\
\hline
\end{tabular}




\begin{tabular}{|c|c|c|c|c|c|c|c|c|c|c|c|}
\hline 16 & $\begin{array}{l}\text { Hardoff et al. } \\
\text { (2013) }\end{array}$ & $\begin{array}{l}\text { No Name, } \\
\text { Israel }\end{array}$ & $16-17$ & 665 & $\begin{array}{c}\text { Pre Post } \\
\text { design }\end{array}$ & $\begin{array}{l}\text { 25\% reported } \\
\text { reduced } \\
\text { drinking }\end{array}$ & $\begin{array}{c}\text { Knowledge } \\
\text { increase, attitude } \\
\text { change reported }\end{array}$ & $\begin{array}{c}\text { Experiential } \\
\text { learning }\end{array}$ & Not reported & No & $\begin{array}{l}\text { Universal } \\
\text { programme }\end{array}$ \\
\hline
\end{tabular}

